\title{
In-situ biogas upgrading process: modeling and simulations aspects
}

Lovato, Giovanna; Alvarado-Morales, Merlin; Kovalovszki, Adam; Peprah, Maria; Kougias, Panagiotis; Rodrigues, José Alberto Domingues; Angelidaki, Irini

Published in:

Bioresource Technology

Link to article, DOI:

10.1016/j.biortech.2017.08.181

Publication date:

2017

Document Version

Peer reviewed version

Link back to DTU Orbit

Citation $(A P A)$ :

Lovato, G., Alvarado-Morales, M., Kovalovszki, A., Peprah, M., Kougias, P., Rodrigues, J. A. D., \& Angelidaki, I. (2017). In-situ biogas upgrading process: modeling and simulations aspects. Bioresource Technology, 245(Part A), 332-341. https://doi.org/10.1016/j.biortech.2017.08.181

\section{General rights}

Copyright and moral rights for the publications made accessible in the public portal are retained by the authors and/or other copyright owners and it is a condition of accessing publications that users recognise and abide by the legal requirements associated with these rights.

- Users may download and print one copy of any publication from the public portal for the purpose of private study or research.

- You may not further distribute the material or use it for any profit-making activity or commercial gain

- You may freely distribute the URL identifying the publication in the public portal 


\section{In-situ biogas upgrading process: Modeling and simulations aspects}

Article in Bioresource Technology · December 2017

DOI: 10.1016/j.biortech.2017.08.181

CITATION

1

7 authors, including:

Giovanna Lovato

University of São Paulo

18 PUBLICATIONS $\mathbf{4 8}$ CITATIONS

SEE PROFILE

Adam Kovalovszki

5. Technical University of Denmark

3 PUBLICATIONS $\mathbf{2 2}$ CITATIONS

SEE PROFILE
492

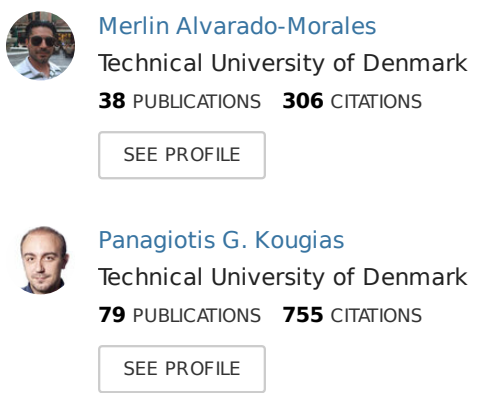

Some of the authors of this publication are also working on these related projects:

SYMBIO Project: Integration of biomass and wind power for biogas enhancement and upgrading via hydrogen assisted anaerobic digestion. View project

Optimisation of value chains for biogas production in Denmark (Biochain) View project 


\section{Accepted Manuscript}

In-situ biogas upgrading process: modeling and simulations aspects

Giovanna Lovato, Merlin Alvarado-Morales, Adam Kovalovszki, Maria

Peprah, Panagiotis G. Kougias, José Alberto Domingues Rodrigues, Irini Angelidaki

PII: S0960-8524(17)31495-5

DOI: http://dx.doi.org/10.1016/j.biortech.2017.08.181

Reference: BITE 18790

To appear in:

Bioresource Technology

Received Date:

30 June 2017

Revised Date:

24 August 2017

Accepted Date:

29 August 2017

Please cite this article as: Lovato, G., Alvarado-Morales, M., Kovalovszki, A., Peprah, M., Kougias, P.G., Rodrigues, J.A.D., Angelidaki, I., In-situ biogas upgrading process: modeling and simulations aspects, Bioresource Technology (2017), doi: http://dx.doi.org/10.1016/j.biortech.2017.08.181

This is a PDF file of an unedited manuscript that has been accepted for publication. As a service to our customers we are providing this early version of the manuscript. The manuscript will undergo copyediting, typesetting, and review of the resulting proof before it is published in its final form. Please note that during the production process errors may be discovered which could affect the content, and all legal disclaimers that apply to the journal pertain. 


\section{IN-SITU BIOGAS UPGRADING PROCESS: MODELING AND SIMULATIONS ASPECTS}

Giovanna Lovato ${ }^{\mathrm{a}}$, Merlin Alvarado-Morales ${ }^{\mathrm{b}}$, Adam Kovalovszki ${ }^{\mathrm{b}}$, Maria Peprah ${ }^{\mathrm{b}}$,

Panagiotis G. Kougias ${ }^{\mathrm{b}}$, José Alberto Domingues Rodrigues ${ }^{\mathrm{a}}$, Irini Angelidaki ${ }^{\mathrm{b}}$

${ }^{a}$ Mauá School of Engineering, Mauá Institute of Technology (EEM/IMT), Praça Mauá

1, CEP 09.580-900, São Caetano do Sul, SP, Brazil.

${ }^{\mathrm{b}}$ Department of Environmental Engineering, Technical University of Denmark, Bygningstorvet Bygning 115, DK-2800 Kgs. Lyngby, Denmark

* Corresponding author: Department of Environmental Engineering, Technical University of Denmark, DK-2800 Kgs. Lyngby, Denmark, Phone: (+45) 45251418;

Fax: (+45) 45933850; e-mail: iria@env.dtu.dk 


\begin{abstract}
Biogas upgrading processes by in-situ hydrogen $\left(\mathrm{H}_{2}\right)$ injection are still challenging and could benefit from a mathematical model to predict system performance. Therefore, a previous model on anaerobic digestion was updated and expanded to include the effect of $\mathrm{H}_{2}$ injection into the liquid phase of a fermenter with the aim of modeling and simulating these processes. This was done by including hydrogenotrophic methanogen kinetics for $\mathrm{H}_{2}$ consumption and inhibition effect on the acetogenic steps. Special attention was paid to gas to liquid transfer of $\mathrm{H}_{2}$. The final model was successfully validated considering a set of Case Studies. Biogas composition and $\mathrm{H}_{2}$ utilization were correctly predicted, with overall deviation below $10 \%$ compared to experimental measurements. Parameter sensitivity analysis revealed that the model is highly sensitive to the $\mathrm{H}_{2}$ injection rate and mass transfer coefficient. The model developed is an effective tool for predicting process performance in scenarios with biogas upgrading.

\section{KEYWORDS}

Biogas upgrading; hydrogenotrophic methanogens; mathematical modelling; sensitivity analysis. 


\section{Introduction}

Anaerobic digestion (AD) is a biological process performed in the absence of oxygen to degrade and stabilize organic matter while producing biogas, a mixture formed mainly of methane $\left(\mathrm{CH}_{4}\right)$ and carbon dioxide $\left(\mathrm{CO}_{2}\right)$ (typically it contains 50$70 \% \mathrm{CH}_{4}, 30-50 \% \mathrm{CO}_{2},<1 \% \mathrm{~N}_{2}$, and 10-2000 $\left.\mathrm{ppm}_{2} \mathrm{~S}\right)$. Biogas can be used for a number of purposes, including electricity production (most common), heat generation and as a raw product for industries (Angelidaki et al., 2006; Mata-Alvarez et al., 2014)

Currently, there is a growing interest in employing biogas coming from the AD treatment as an alternative to natural gas. By removing the $\mathrm{CO}_{2}$ present in biogas the energy content is increased so that it can be used as vehicle fuel or be injected into natural gas distribution grids (Sun et al., 2015). Therefore, "biogas upgrading" is the process that involves the removal of $\mathrm{CO}_{2}$ and water vapor, as well as typical contaminants such as hydrogen sulfide, siloxanes, dust and particles. The final gas is called "biomethane" if it is purified to natural gas standards (Kougias et al., 2017).

Traditional methods for biogas upgrading include membranes, water physical scrubber, pressure swing adsorption, polyglycol adsorption, chemical treatments and cryogenic upgrading (Osorio and Torres, 2009). These are performed outside the anaerobic reactor and require investments in external equipment such as compressors, pumps, membranes, etc. (Luo and Angelidaki, 2013) and consume considerable amounts of electricity and/or heat. Based on the process technology used, the cost of biogas upgrading has been estimated to be in the range of $0.12-0.44 € / \mathrm{Nm}^{3}$ of biogas (Hullu et al., 2008). 
As an alternative to the conventional biogas upgrading process, biogas can also be upgraded by biological coupling of hydrogen $\left(\mathrm{H}_{2}\right)$ with $\mathrm{CO}_{2}$ present in the biogas to convert it to $\mathrm{CH}_{4}$. For this purpose, $\mathrm{H}_{2}$ can be produced by water electrolysis using the surplus of electricity generated from wind mills or photovoltaic facilities (Ursua et al., 2012). The biochemical reaction between $\mathrm{H}_{2}$ and $\mathrm{CO}_{2}$ is performed by a group of microorganisms known as hydrogenotrophic methanogenic archaea that $\mathrm{use}^{\mathrm{CO}} \mathrm{O}_{2}$ as carbon source and $\mathrm{H}_{2}$ as electron donor to produce $\mathrm{CH}_{4}$ (Muñoz et al., 2015). Recent studies have documented that the injection of $\mathrm{H}_{2}$ into a conventional biogas reactor can result in up to $45 \%$ increase in $\mathrm{CH}_{4}$ productivity, as the result of the carbon dioxide conversion present in the biogas to additional $\mathrm{CH}_{4}$ (Bassani et al., 2016; Luo et al., 2012; Luo and Angelidaki, 2013).

The hydrogen injection can be performed in two different ways: (i) in-situ, in which $\mathrm{H}_{2}$ is injected directly into the liquid phase of a conventional AD reactor where it will couple with endogenous (internally produced by the process) $\mathrm{CO}_{2}$ and (ii) ex-situ, in which (exogenous from external sources) $\mathrm{CO}_{2}$ and $\mathrm{H}_{2}$ are injected inside the liquid phase of a reactor containing enhanced hydrogenotrophic cultures (Kougias et al., 2017).

Although biological biogas upgrading may be economically advantageous compared to conventional methods, $\mathrm{H}_{2}$ mediated in-situ biogas upgrading still involves some technical challenges that need to be solved. For instance, direct $\mathrm{H}_{2}$ injection into the $\mathrm{AD}$ reactor can lead to a substantial decrease of $\mathrm{pH}$ - primarily due to $\mathrm{CO}_{2}$ uptake by hydrogenotrophic methanogens -thereby affecting process stability negatively. Along with this, $\mathrm{H}_{2}$ mass transfer to the liquid phase still remains the limiting step (Bassani et al., 2015; Luo et al., 2012; Luo and Angelidaki, 2013). Thus, it is of major 
importance to address these challenges to obtain optimal and stable process operation of this technology in the long term.

Mathematical models can provide insights into understanding and analyzing important aspects (inhibition pathways, policies for start-up, operation and optimization) associated with the anaerobic digestion process. Also, the use of reliable mathematical models minimizes experimental effort, risk and cost (Angelidaki et al., 1999). Therefore, the aim of the present work was to model and simulate the biogas upgrading process by in-situ hydrogen injection accurately. The range of application of a mathematical model for anaerobic bioconversion of complex substrates was extended by incorporating the hydrogenotrophic pathway into the model kinetics as well as the $\mathrm{H}_{2}$ mass transfer process. Two case studies were used for the validation of the extended bioconversion model. Finally, a parameter sensitivity analysis was performed to investigate the influence of the new set of parameters included in the model (kinetic constants for hydrogenotrophic methanogens and hydrogen inhibition, global mass transfer coefficient $\left(\mathrm{k}_{\mathrm{L}} \mathrm{a}\right)$ of the main gases and volumetric flowrate injection of hydrogen) on the output variables of the model (biogas, methane, carbon dioxide and hydrogen rates, $\mathrm{pH}$, and total ammonium nitrogen concentration).

\section{Material and methods}

\subsection{Modeling approach}

\subsubsection{BioModel description}

The core bioconversion model, namely "BioModel" in this work, was developed by Angelidaki et al. (1999, 1993) and recently extended by Kovalovszki et al. (2017) for 
modeling and simulation of various co-digestion scenarios. The BioModel describes complex substrates degradation with the co-digestion of different types of organic wastes. The substrates are described in terms of their basic organic components' composition (carbohydrates, lipids, and proteins), organic acids and inorganic components (ammonia, phosphate, cations, anions, etc.). The model includes three enzymatic hydrolytic processes and eight bacterial steps. It involves 19 chemical compounds, together with a detailed description of $\mathrm{pH}$ and temperature characteristics. Free ammonia, volatile fatty acids (VFAs) and long chain fatty acids (LCFAs) constitute the primary modulating factors. Inhibitions, interactions, and stoichiometry of the components and equations applied in the model are described in Angelidaki et al. (1999) and can be found in the supplementary material provided in this paper. The current model uses the optimal kinetic and yield parameters estimated by Kovalovszki et al. (2017) for Angelidaki's model, which are also provided in the supplementary material.

Fig. 1 shows the main pathways of the process. The model involves the following enzymatic processes: (A) hydrolysis of undissolved lipids (based on Weinrich and Nelles, 2015), (B) hydrolysis of undissolved carbohydrates, and (C) hydrolysis of undissolved proteins, and the bacterial groups: (1) glucose-fermenting acidogens, (2) amino acid-degrading acidogens, (3) glycerol trioleate (GTO)-degrading acidogens (4) long chain fatty acids (LCFA)-degrading acetogens, (5) propionate, (6) butyrate, (7) valerate-degrading acetogens, (8) aceticlastic methanogens and, finally, (9) hydrogenotrophic methanogens for the biogas upgrading that were included in the model. 
The biochemical reactions and yield coefficients derived from stoichiometry of all steps can be found in the supplementary material.

\subsubsection{Incorporation of hydrogenotrophic pathway and gas mass transfer rates}

It is important to note that, in the original BioModel, hydrogen kinetics were merged into other steps (omitted), as endogenous hydrogen utilization is faster compared to the other metabolic pathways and therefore this pathway was not considered as a separate kinetic step (Lima et al., 2016). Therefore, in the current model development, in order to couple the $\mathrm{CO}_{2}$ present in biogas with an external $\mathrm{H}_{2}$ supply the BioModel has been expanded by incorporating the hydrogenotrophic pathway (Equation 1) proposed by Hill (1982):

$$
\mathrm{H}_{2}+0.0058 \mathrm{NH}_{3}+0.2644 \mathrm{CO}_{2} \rightarrow 0.0058 \mathrm{C}_{5} \mathrm{H}_{7} \mathrm{NO}_{2}+0.2355 \mathrm{CH}_{4}+0.5171 \mathrm{H}_{2} \mathrm{O}
$$

Although hydrogenotrophic methanogenesis, homoacetogenesis, syntrophic acetogenesis and synthrophic acetate oxidation are competing pathways, the former prevails because the injection of hydrogen close to microbial communities inhibits syntrophic acetogenesis and syntrophic acetate oxidation, as these processes are getting less energetically favourable. Between hydrogenotrophic methanogenesis and homoacetogenesis, the first is more energetically favourable and it has been shown to be the dominant process in reactors feed with $\mathrm{H}_{2}$ (Garcia-Robledo et al., 2016).

The kinetics for the hydrogenotrophic methanogens ( $\mu_{\mathrm{X}_{9}}$ - Equation 2) were based on Batstone et al (2002) and Siegrist et al. (2002), considering Monod type kinetics for hydrogen and ammonium (primary substrates), non-competitive inhibition by LCFA and the effect of $\mathrm{pH}$ on the growth rate was modelled by the Michaelis $\mathrm{pH}$ function described in Angelidaki et al. (1993). Expressions in square brackets represent the 
concentration $\left(\mathrm{g} \cdot \mathrm{L}^{-1}\right)$ of the respective components. Also, non-competitive hydrogen inhibition kinetics were added to acetogenic microorganisms according to Siegrist et al. (2002). Kinetic models and their corresponding constants for all the main pathways considered in the model are summarized in in the supplementary material.

$$
\mu_{\mathrm{X}_{9}}=\mu_{\mathrm{max}, \mathrm{X}_{9}}(\mathrm{~T}) \cdot \mathrm{FpH}(\mathrm{t}) \cdot \frac{\left[\mathrm{H}_{2}\right]}{\mathrm{K}_{\mathrm{S}, \mathrm{X}_{9}}+\left[\mathrm{H}_{2}\right]} \cdot \frac{\left[\mathrm{NH}_{4}^{+}\right]}{\mathrm{K}_{\mathrm{S}, \mathrm{NH}_{4}, \mathrm{X}_{9}}+\left[\mathrm{NH}_{4}^{+}\right]} \cdot \frac{1}{1+\frac{[\mathrm{LCFA}]}{\mathrm{K}_{\mathrm{i}, \mathrm{LCFA}, \mathrm{X}_{9}}}}-\mathrm{K}_{\mathrm{d}, \mathrm{X}_{9}}
$$

All the reactions (chemical and biochemical) take place in the liquid phase (gas phase is non-reactive), and both phases are homogeneous. Equation 3 shows the balance for non-volatile components. Mass balance for volatile components in the liquid and gas phases were also modified with respect to the original BioModel, which takes into consideration a quasi-stationary equilibrium to calculate the distribution of the volatile components between gas and liquid phases (Angelidaki et al., 1993). Mass transfer rate terms for volatile components $\left(\mathrm{NH}_{3}, \mathrm{CH}_{4}, \mathrm{CO}_{2}, \mathrm{H}_{2} \mathrm{~S}\right)$ were incorporated into the mass balances resulting in Equations 4 and 5.

For non-volatile components in the liquid phase:

$$
\frac{\mathrm{d}[\mathrm{S}]_{\mathrm{L}}}{\mathrm{dt}}=\frac{\mathrm{q}_{\mathrm{L}, \text { in }}}{\mathrm{V}_{\mathrm{L}}} \cdot[\mathrm{S}]_{\mathrm{L}, \text { in }}-\frac{\mathrm{q}_{\mathrm{L}, \text { out }}}{\mathrm{V}_{\mathrm{L}}} \cdot[\mathrm{S}]_{\mathrm{L}, \text { out }}+\sum_{i=1}^{9} \mathrm{Y}_{\mathrm{S} / \mathrm{X}_{\mathrm{i}}} \cdot \mu_{\mathrm{i}} \cdot \mathrm{X}_{\mathrm{i}}
$$

For volatile components in the liquid phase:

$$
\frac{\mathrm{d}[\text { gas }]_{\mathrm{L}}}{\mathrm{dt}}=\frac{\mathrm{q}_{\mathrm{L}, \text { in }}}{\mathrm{V}_{\mathrm{L}}} \cdot[\text { gas }]_{\mathrm{L}, \text { in }}-\frac{\mathrm{q}_{\mathrm{L}, \text { out }}}{\mathrm{V}_{\mathrm{L}}} \cdot[\text { gas }]_{\mathrm{L}}+\sum_{i=1}^{9} \mathrm{Y}_{\mathrm{S} / \mathrm{X}_{\mathrm{i}}} \cdot \mu_{\mathrm{i}} \cdot \mathrm{X}_{\mathrm{i}}-\mathrm{k}_{\mathrm{L}} \mathrm{a}_{\text {gas }} \cdot\left([\text { gas }]_{\mathrm{L}}-[\text { gas }]_{\mathrm{L}}^{*}\right)
$$

For volatile components in the gas phase:

$$
\frac{\mathrm{d}[\text { gas }]_{\mathrm{G}}}{\mathrm{dt}}=-\frac{\mathrm{q}_{\mathrm{G}, \text { out }}}{\mathrm{V}_{\text {HeadSpace }}} \cdot[\text { gas }]_{\mathrm{G}}+\frac{\mathrm{V}_{\mathrm{L}}}{\mathrm{V}_{\text {HeadSpace }}} \cdot \mathrm{k}_{\mathrm{L}} \mathrm{a}_{\text {gas }} \cdot\left([\text { gas }]_{\mathrm{L}}-[\text { gas }]_{\mathrm{L}}^{*}\right)
$$


Where $\mathrm{S}$ is any of the non-volatile components in the model (carbohydrates, lipids, proteins and organic acids), $\mathrm{q}_{\mathrm{L}, \text { in }}$ is the liquid volumetric flow entering the reactor $\left(\mathrm{L} \cdot \mathrm{h}^{-}\right.$ $\left.{ }^{1}\right), \mathrm{q}_{\mathrm{L}, \text { out }}$ is the liquid volumetric flow leaving the reactor $\left(\mathrm{L} \cdot \mathrm{h}^{-1}\right), \mathrm{V}_{\mathrm{L}}$ is liquid volume of the reactor $(\mathrm{L}), \mathrm{Y}_{\mathrm{S} / \mathrm{Xi}}$ is the yield coefficient derived from stoichiometry $\left(\mathrm{g} \cdot \mathrm{g}_{\text {biomass }}{ }^{-1}\right), \mu_{\mathrm{i}}$ is the kinetic equation for each microbial group $\left(h^{-1}\right), X_{i}$ is the concentration of each microbial group $\left(\mathrm{g} \cdot \mathrm{L}^{-1}\right), \mathrm{q}_{\mathrm{G}, \text { out }}$ is the gas volumetric flowrate $\left(\mathrm{L} \cdot \mathrm{h}^{-1}\right)$ leaving the reactor and $\mathrm{V}_{\text {HeadSpace }}$ is the head space volume of the reactor $(\mathrm{L})$.

In Equations 4 and 5, the driving force for the transfer from the liquid phase to the gas phase is expressed as the difference between the actual concentration of dissolved gas and the concentration that would be in equilibrium with the partial pressure of the given species in the gas phase (Pauss et al., 1990), the latter being calculated by Henry's law (Equation 6), where $\mathrm{P}_{\text {gas }}$ is the partial pressure (atm) of the gas and $\mathrm{K}_{\mathrm{H}, \mathrm{gas}}$ is Henry's constant for the gas $\left(\mathrm{g} \cdot \mathrm{L}^{-1} \cdot \mathrm{atm}^{-1}\right)$ :

$[\text { gas }]_{\mathrm{L}}^{*}=\mathrm{P}_{\mathrm{gas}} \cdot \mathrm{K}_{\mathrm{H}, \mathrm{gas}}$

The global mass transfer coefficient, $\mathrm{k}_{\mathrm{L}} \mathrm{a}\left(\mathrm{h}^{-1}\right)$, is representative of the rate of transfer in either direction (gas to liquid or liquid to gas) for the whole reactor. According to Pauss et al. (1990), the $\mathrm{k}_{\mathrm{L}}$ a of the different gases in the medium are proportional to the square root of their diffusivity (Equation 7) and they are affected by design and operating parameters (such as mixing, liquid quality and gas pressure):

$\left(\mathrm{k}_{\mathrm{L}} \mathrm{a}\right)_{\mathrm{CH}_{4}}=\left(\mathrm{k}_{\mathrm{L}} \mathrm{a}\right)_{\mathrm{CO}_{2}} \cdot \sqrt{\frac{D_{\mathrm{CH}_{4}}}{D_{\mathrm{CO}_{2}}}}$

The $\mathrm{k}_{\mathrm{L}}$ a of these gases $\left(\mathrm{NH}_{3}, \mathrm{CH}_{4}, \mathrm{CO}_{2}\right.$ and $\left.\mathrm{H}_{2} \mathrm{~S}\right)$ were calibrated to provide the best prediction possible to the three case studies presented in this paper, by minimizing the error between experimental data and model prediction by adjusting only this parameter. 
The starting point was the value for the methane $\mathrm{k}_{\mathrm{L}} \mathrm{a}$ given by Pauss et al. (1990) for a CSTR reactor $\left(0.09 \mathrm{~h}^{-1}\right)$. The values used for this model are: $\left(\mathrm{k}_{\mathrm{L}} \mathrm{a}\right)_{\mathrm{NH}_{3}}=0.295 \mathrm{~h}^{-1}$, $\left(\mathrm{k}_{\mathrm{L}} \mathrm{a}\right)_{\mathrm{CH}_{4}}=0.261 \mathrm{~h}^{-1},\left(\mathrm{k}_{\mathrm{L}} \mathrm{a}\right)_{\mathrm{CO}_{2}}=0.294 \mathrm{~h}^{-1},\left(\mathrm{k}_{\mathrm{L}} \mathrm{a}\right)_{\mathrm{H}_{2} \mathrm{~S}}=0.265 \mathrm{~h}^{-1}$. Those values are also in agreement with the work of Feng et al. (2006), who stated that values of $\mathrm{k}_{\mathrm{L}}$ a smaller than $0.04 \mathrm{~h}^{-1}$ can cause impairment to biogas production rate.

Therefore, considering mass transfer rate phenomena, the mass balance equations for $\mathrm{H}_{2}$, when it is continuously added/injected to and removed from the liquid phase, can be written as follows for the liquid-phase (Equation 8) and the gas phase (Equation 9):

$$
\begin{aligned}
& \frac{\mathrm{d}\left[\mathrm{H}_{2}\right]_{\mathrm{L}}}{\mathrm{dt}}=\frac{\mathrm{F}_{\text {in }}}{\mathrm{V}_{\mathrm{L}}} \cdot\left[\mathrm{H}_{2}\right]_{\mathrm{L}, \text { in }}-\frac{\mathrm{F}_{\text {out }}}{\mathrm{V}_{\mathrm{L}}} \cdot\left[\mathrm{H}_{2}\right]_{\mathrm{L}, \text { out }}+\mathrm{Y}_{\mathrm{H}_{2} / \text { Hyd.met }} \cdot \mu_{\mathrm{X}_{9}} \cdot \mathrm{X}_{9}+\mathrm{k}_{\mathrm{L}} \mathrm{a}_{\mathrm{H}_{2}} \cdot\left(\left[\mathrm{H}_{2}\right]_{\mathrm{L}}^{*}-\left[\mathrm{H}_{2}\right]_{\mathrm{L}}\right) \\
& \frac{\mathrm{d}\left[\mathrm{H}_{2}\right]_{\mathrm{G}}}{\mathrm{dt}}=\frac{\mathrm{q}_{\mathrm{G}, \text { in }}}{\mathrm{V}_{\text {HeadSpace }}} \cdot\left[\mathrm{H}_{2}\right]_{\mathrm{G}, \text { in }}-\frac{\mathrm{q}_{\mathrm{G}, \text { out }}}{\mathrm{V}_{\text {Heads pace }}} \cdot\left[\mathrm{H}_{2}\right]_{\mathrm{G}}-\frac{\mathrm{V}_{\mathrm{L}}}{\mathrm{V}_{\text {HeadSpace }}} \cdot \mathrm{k}_{\mathrm{L}_{\mathrm{H}_{2}}} \cdot\left(\left[\mathrm{H}_{2}\right]_{\mathrm{L}}^{*}-\left[\mathrm{H}_{2}\right]_{\mathrm{L}}\right)
\end{aligned}
$$

Where in Equation (9) $\mathrm{q}_{\mathrm{G}, \text { in }}$ is the hydrogen injection volumetric flowrate $\left(\mathrm{L}^{-1} \cdot \mathrm{h}^{-1}\right)$ and $\left[\mathrm{H}_{2}\right]_{\mathrm{G} \text {,in }}$ is the hydrogen concentration in the inlet at the temperature and pressure (1 atm) of the reactor:

In the case of the hydrogen injection process, the $\left(\mathrm{k}_{\mathrm{L}} \mathrm{a}\right)_{\mathrm{H}_{2}}$ will be a function of the mixing speed, gas recirculation and $\mathrm{H}_{2}$ diffusion device (Bassani et al., 2016; Luo and Angelidaki, 2013). Thus, based on the operating conditions, $\left(\mathrm{k}_{\mathrm{L}} \mathrm{a}\right)_{\mathrm{H}_{2}}$ is an input parameter that must be provided to the model.

The volumetric gas flowrate leaving the reactor $\left(\mathrm{q}_{\mathrm{G}, \text { out }}\right)$ was calculated according to Batstone et al. (2002) (Equation 10), taking into account the five gases $\left(\mathrm{NH}_{3}, \mathrm{CH}_{4}, \mathrm{CO}_{2}\right.$, $\mathrm{H}_{2} \mathrm{~S}$ and $\mathrm{H}_{2}$ ) mass transfer rates - where $\mathrm{R}$ is the ideal gas constant $\left(\mathrm{atm} \cdot \mathrm{L} \cdot \mathrm{mol}^{-1} \cdot \mathrm{K}^{-1}\right), \mathrm{T}$ 
is the temperature of the reactor $(\mathrm{K}), \mathrm{P}_{\mathrm{R}}$ is the reactor's pressure (atm), $\mathrm{P}_{\mathrm{H}_{2} \mathrm{O}}(\mathrm{atm})$ is the water vapor pressure and $\mathrm{MM}_{\mathrm{G}}$ is the molar mass for each gas $\left(\mathrm{g} \cdot \mathrm{mol}^{-1}\right)$ :

$\mathrm{q}_{\mathrm{G}, \text { out }}=\frac{\mathrm{R} \cdot \mathrm{T}}{\mathrm{P}_{\mathrm{R}}-\mathrm{P}_{\mathrm{H}_{2} \mathrm{O}}} \cdot \mathrm{V}_{\mathrm{L}} \cdot\left(\sum_{i=1}^{5} \mathrm{k}_{\mathrm{L}} \mathrm{a}_{\text {gas }} \cdot\left(\frac{[\text { gas }]_{\mathrm{L}}-[\text { gas }]_{\mathrm{L}}^{*}}{\mathrm{MM}_{\mathrm{G}}}\right)\right)$

\subsection{Computational methods}

The BioModel was implemented in MATLAB, combined with a Microsoft Excelbased data input and output platform. The model is able to simulate the AD process (mono or co-digestion) in one continuously stirred tank reactor (CSTR), considering the characteristics of the inoculum and up to four substrates. Structure and calculation of model parameters (kinetics, chemical components and output variables) was performed similarly as described by Angelidaki et al. (1999) with the new implementations described in this paper. The solution of the ordinary differential equation system was solved using the MATLAB's ODE15s Solver (Kovalovszki et al., 2017).

\subsection{Parameter sensitivity analysis}

A sensitivity analysis was performed on the parameters that were implemented in this new version of the BioModel: kinetic constants for hydrogenotrophic methanogens and hydrogen inhibition, $\mathrm{k}_{\mathrm{L}}$ a of the main gases and volumetric gas flowrate injection of hydrogen. The objective was to evaluate the magnitude of the parameters' individual effect on the following output variables: biogas, methane, carbon dioxide and hydrogen rate (all gaseous), $\mathrm{pH}$, and total ammonium nitrogen (TAN) concentration, which are the variables that are most affected by the biogas upgrading (Luo and Angelidaki, 2013). 
Sampling of the available parameter space was performed with the Latin Hypercube Sampling (LHS) method assuming uniform parameter distribution.

Following the sampling process, simulations were performed with every set of parameter samples generated previously. The simulations were performed with the conditions of Case Study 2 (which is explained in section 2.5.2) since it was the one that showed the best prediction by the model. The sampling-based, Partial Rank Correlation Coefficient (PRCC) method was used to perform the sensitivity analysis. Both LHS and the PRCC analyses were carried out using the MATLAB-based Sampling and Sensitivity Analyses Tool (SaSAT) (Hoare et al., 2008). The detailed method for the sensitivity analyses can be found in Kovalovszki et al. (2017).

\subsection{Model validation}

Experimental work of Luo and Angelidaki (2013), Fitamo et al. (2016a, 2016b) and own unpublished data were used for model validation.

Firstly, the validation of the calculation of the gas phase considering the global mass transfer rate for gaseous components was performed with experimental data taken from Fitamo et al. (2016a, 2016b) (Case Study 1) and the control reactor from Luo and Angelidaki (2013) (Case Study 2), which was operated without hydrogen injection.

Then, for the validation of the biogas upgrading process implementation, the reactor with hydrogen injection of Luo and Angelidaki (2013) (Case Study 2) and a reactor fed with cheese whey and manure with hydrogen injection (Case Study 3 - unpublished data) were used. 


\subsection{Case Studies}

Below a short overview of the three experimental case studies is presented, which were used for model validation.

\subsubsection{Case Study 1}

The experiment published by Fitamo et al. (2016a, 2016b) was used as material for the validation of the new calculation of the gas phase. In their work, co-digestion of wastewater sludge with different organic wastes (food waste, grass clippings and garden waste) was evaluated in two reactors, although only the first one is considered in this study (see Table 1).

According to the description of the process, five feeding periods were defined during the experiment, where the first covered only municipal sludge digestion and the other four were performed with the co-digestion of the four substrates $(10: 68: 15: 7-$ $\% \mathrm{VS}$ ). Hydraulic retention time (HRT) was altered during the five periods as follows: period 1 (75 days) with mono digestion with HRT of 30 days; period 2 (56 days) with co-digestion with HRT of 30 days; period 3 (34 days) with co-digestion with HRT of 20 days; period 4 (40 days) with co-digestion with HRT of 15 days; and period 5 (26 days) with co-digestion with HRT of 10 days. The reactor working volume was 7.0 L and operation temperature was $55^{\circ} \mathrm{C}$. The authors agreed that Fitamo et al.'s work would be a good choice for validation of the gas phase due to the complex substrates that were used and for the changes in the HRT that were performed.

\subsubsection{Case Study 2}

Case Study 2 consists of the two reactors of Luo and Angelidaki (2013): the control reactor and the reactor with biogas upgrading. The control reactor (without hydrogen injection) was used as a validation for the gas phase calculation either since the reactor 
with hydrogen injection of their paper is vital for the validation of the biogas upgrading modeling. Both reactors were CSTRs of $1.0 \mathrm{~L}$ operated with HRT of 15 days at $55{ }^{\circ} \mathrm{C}$. They were fed with a mixture of diluted cheese whey and manure at ratio of 2:3 of volatile solids. The $\mathrm{H}_{2}$ injection rate in the reactor with biogas upgrading was initially set at $1.5 \mathrm{~L} \cdot \mathrm{L}^{-1} \cdot \mathrm{d}^{-1}$, and then changed to $1.7 \mathrm{~L} \cdot \mathrm{L}^{-1} \cdot \mathrm{d}^{-1}$ after 20 days and maintained at that value until the end of operation. Mixing speed and hydrogen diffuser were changed during operation resulting in $\left(\mathrm{k}_{\mathrm{L}} \mathrm{a}\right)_{\mathrm{H}_{2}}$ of $6.6 \mathrm{~h}^{-1}, 11.2 \mathrm{~h}^{-1}$ and $16.1 \mathrm{~h}^{-1}$ for periods 2,3 and 4, respectively. Table 2 presents the characteristics both experiments.

\subsubsection{Case Study 3}

The third and last case study is based on own experiments that are yet to be published. The experimental setup consists of a CSTR of $1.8 \mathrm{~L}$ operated at HRT of 15 days at $55^{\circ} \mathrm{C}$. It was fed with a mixture of diluted cheese whey and manure at a ratio of 80:20 of volatile solids for 140 days. The authors chose to study this experiment due to the high level of instability that this proportion of cheese whey causes to a reactor, in fact, the $20 \%$ of manure was only added to the influent because it was not possible to stabilize the reactor with only cheese whey. The first period of operation is only the proposed co-digestion operated for 23 days and the second period of operation is the codigestion of the substrates with $\mathrm{H}_{2}$ injection rate of $0.8 \mathrm{~L} \cdot \mathrm{L}^{-1} \cdot \mathrm{d}^{-1}$ for 86 days with a $\left(\mathrm{k}_{\mathrm{L}} \mathrm{a}\right)_{\mathrm{H}_{2}}$ of $40 \mathrm{~h}^{-1}$. Table 3 presents the characteristics of the experiment.

\section{Results and discussion}

Simulations utilizing the new BioModel were performed for each case study. The response of the model in terms of biogas, methane and hydrogen volumetric gas flow 
rates, $\mathrm{pH}$, total ammonia and total volatile fatty acids concentrations are presented for all Case Studies. For the Case Studies 2 and 3 (experimental data with biogas upgrading), biogas composition is also presented.

\subsection{Case study 1}

BioModel simulation results together with the experimental data of Fitamo et al. (2016 a, b) are presented in Figure 2. It can be noticed that biogas and, especially, methane productivity were captured very well by model (a), with a maximum error of $27.2 \%$ in the steady state of period 1 and a minimum error of $4.1 \%$ in period $5 . \mathrm{pH}(\mathrm{b})$ was also captured well by the model with an error that varied between 2.1 and $4.2 \%$ in all periods; total ammonia concentration (b) was not captured as precisely as volumetric gas flow rates and $\mathrm{pH}$, although it can be seen that the trend is very well described due to the use of Kovalovszki et al.'s optimized parameters (dashed lines in Figure 2).

The total VFA simulation (c), however, showed higher levels compared to the experimental trend, which can be an indicator that in the experimental operation the acid-consuming microorganisms had faster kinetics than assumed in the model maybe due to better adapted microbial consortia to the process conditions. The simulated peak in period 2 is probably the result of starting the co-digestion period, since food waste contained high amounts of soluble substrate (Kovalovszki et al., 2017).

\subsection{Case study 2}

\subsubsection{Control reactor}

Simulation results and the experimental data of Luo and Angelidaki (2013) are presented in Figure 3. As observed, biogas and methane productivity (a) were captured well by the model, with an error for the steady state period of $5.9 \%$ for the biogas and 
$11.8 \%$ for the methane. The difference between experimental methane and simulated methane can be explained by the low $\left(\mathrm{k}_{\mathrm{L}} \mathrm{a}\right)_{\mathrm{CH}_{4}}$ that Luo and Angelidaki found for the control reactor $\left(0.03 \mathrm{~h}^{-1}\right)$ which indicates a limited mass transfer rate (Feng et al., 2006).

$\mathrm{pH}$ (b) experimental trend was also well captured by the model, with an absolute error in the steady state period of only 1.8\%. Luo and Angelidaki (2013) did not provide ammonia concentrations data for the entire experimental period, however authors reported ammonia concentration when the system reached steady state conditions. For the control reactor, this concentration corresponded to approximately $0.52 \pm 0.03 \mathrm{~g}-\mathrm{N} \cdot \mathrm{L}^{-}$ ${ }^{1}$ and the model output corresponded to a concentration of $0.59 \mathrm{~g}-\mathrm{N} \cdot \mathrm{L}^{-1}$.

The total VFA simulation (c) showed higher levels compared to the experimental trend and was unable to predict the volatile acids peak in the transient period. The difference between the simulated and experimental VFA at steady-state condition was of $54.5 \%$.

Since biogas, methane and $\mathrm{pH}$ were sufficiently close to experimental results for Case Study 1 and 2 (control reactor), the authors considered that the modeling for the calculation of the gas phase was validated and proceeded for the validation of the modeling of the biogas upgrading.

\subsubsection{Reactor with biogas upgrading}

Results of the simulation and experimental data taken from Luo and Angelidaki (2013) are presented in Figure 4. Biogas and methane productivities (a) were well predicted by the model, with errors varying for the steady state periods between 3.4 and $6.3 \%$ for the biogas, 3.2 and $14.5 \%$ for the methane and 14.8 and $29.2 \%$ for the hydrogen. Looking at the biogas composition graph (b) it is possible to observe that the model is indeed calculating all the gas compositions and rates according to the 
experimental trend. Analyzing those two graphs, we can see the model predicting that as $\left(\mathrm{k}_{\mathrm{L}} \mathrm{a}\right)_{\mathrm{H}_{2}}$ increases, more hydrogen is dissolved into the liquid phase, therefore decreasing the hydrogen in the gas phase. As more hydrogen is dissolved into the liquid phase, more methane is generated and less carbon dioxide leaves the reactor as it is consumed by hydrogenotrophic methanogens (microbial concentrations simulated by the model are provided in the supplementary material). This leads to a decrease in the overall biogas production rate, since hydrogen and carbon dioxide rates are decreasing.

Hydrogen partial pressure was also correctly predicted by the model: in period 2, experimental pressure was recorded to be $36 \mathrm{kPa}$ and the model calculated $30 \mathrm{kPa}$; in period 3, experimental pressure was $23.8 \mathrm{kPa}$ and the model calculated $21.3 \mathrm{kPa}$ and, in period 4, experimental pressure was $18.4 \mathrm{kPa}$ and the model calculated $17 \mathrm{kPa}$.

Moving on to $\mathrm{pH}$ and ammonia simulation (c), it is worth mentioning that the model predicted correctly the increase in $\mathrm{pH}$ due to the $\mathrm{HCO}_{3}{ }^{-}$consumption by hydrogenotrophic methanogens. The difference between simulation and experimental data for $\mathrm{pH}$ was between 1.3 and $1.9 \%$ for all periods, reinforcing the correct prediction of the model for this parameter. Regarding ammonia concentration, at steady state conditions, the reactor had approximately $0.52 \pm 0.03 \mathrm{~g}-\mathrm{N} \cdot \mathrm{L}^{-1}$ and model prediction corresponded to a concentration of $0.54 \mathrm{~g}-\mathrm{N} \cdot \mathrm{L}^{-1}$.

The total VFA simulation (d), as for the other case studies, showed higher levels than seen during the experiment and was unable to predict the peak of volatile acids in the beginning of the operation. The difference between the simulated and experimental VFA at steady-state condition was of $48.6 \%$.

A simulation was run in order to determine the threshold of the hydrogen injection (using $\left(\mathrm{k}_{\mathrm{L}} \mathrm{a}\right)_{\mathrm{H}_{2}}$ of $\left.16 \mathrm{~h}^{-1}\right)$ that would increase the $\mathrm{pH}$ to a point where process failure 
occurs. The hydrogen injection limit was found to be $2.3 \mathrm{~nL} \cdot \mathrm{L}^{-1} \cdot \mathrm{d}^{-1}$ : beyond this value, $\mathrm{pH}$ increases to over 8.4 and the microbial groups start to decay. It is worthy to say that this value is in excess comparing to the one calculated as necessary by the stoichiometry, which would be $1.5 \mathrm{~nL} \cdot \mathrm{L}^{-1} \cdot \mathrm{d}^{-1}$ (calculating four times the amount of carbon dioxide produced by the control reactor).

\subsection{Case study 3}

Results of the simulation with the unpublished experimental data are presented in Figure 5. Biogas and methane productivity and hydrogen rate (a) were captured well by the model, even though the reactor presented far more unstable data than Luo and Angelidaki (2013) due to the high quantity of cheese whey in the influent. Errors for the steady state period with hydrogen injection were $10.3 \%$ for the biogas, $8.7 \%$ for the methane and $21.1 \%$ for the hydrogen. As in Case Study 2, the model predicts correctly that when hydrogen injection takes place, there is an increase in methane and a decrease in carbon dioxide percentage, respectively (b). The instability seen in days $85-100$ is due to minor, unexpected problems with the gas chromatograph so that accurate measurements were not possible to obtain.

In this case, the overall biogas production increased from period 1 to 2 , because a period without and one with hydrogen injection were compared. Accordingly, methane productivity increased from approximately 0.90 to $1.05 \mathrm{~nL} \cdot \mathrm{L}^{-1} \cdot \mathrm{d}^{-1}$, carbon dioxide decreased from 0.47 to $0.32 \mathrm{~nL} \cdot \mathrm{L}^{-1} \cdot \mathrm{d}^{-1}$ and the volumetric flowrate of unconsumed hydrogen was $0.08 \mathrm{~nL} \cdot \mathrm{L}^{-1} \cdot \mathrm{d}^{-1}$. The model has predicted this effect correctly.

$\mathrm{pH}$ simulation (c) was highly accurate for the period with hydrogen injection, with an error of $1.4 \%$. In this simulation, it is also noticeable how the $\mathrm{pH}$ increases from 7.7 
to 7.9 after the hydrogen injection due to the $\mathrm{HCO}_{3}{ }^{-}$consumption. Experimental data for ammonia concentration were not available.

Finally, total VFA simulation (d) showed much higher levels than seen during the experiment, proving that this parameter's simulation can be quite challenging and still needs improvement. The results of the simulations, although showing general agreement with the observed trends of experimental data except the peaks, indicate that the model is unable to account for the degradation of organic acids, without further manipulation of the kinetic parameters. This divergence can be caused by different metabolic routes that are not comprised by the current model or by better adapted microbial consortia to the process conditions. Before major structural changes to the model are considered, however, more experimental data on the characterization of the kinetics of microorganisms is necessary (Costello et al., 1991; Kovalovszki et al., 2017).

\subsection{Sensitivity analysis}

A sensitivity analysis was performed on the kinetic constants for hydrogenotrophic methanogens $\left(\mu_{\max , \mathrm{X}_{9}}, \mathrm{~K}_{\mathrm{S}, \mathrm{X}_{9}}, \mathrm{~K}_{\mathrm{S}, \mathrm{NH}_{4}, \mathrm{X}_{9}}\right.$ and $\left.\mathrm{K}_{\mathrm{d}, \mathrm{X}_{9}}\right)$ and hydrogen inhibition $\left(\mathrm{K}_{\mathrm{i}, \mathrm{H}_{2}, \mathrm{X}_{4}}\right.$, $\mathrm{K}_{\mathrm{i}, \mathrm{H}_{2}, \mathrm{X}_{5}}, \mathrm{~K}_{\mathrm{i}, \mathrm{H}_{2}, \mathrm{X}_{6}}$ and $\left.\mathrm{K}_{\mathrm{i}, \mathrm{H}_{2}, \mathrm{X}_{7}}\right)$, the $\mathrm{k}_{\mathrm{L}} \mathrm{a}$ of the main gases $\left(\left(\mathrm{k}_{\mathrm{L}} \mathrm{a}\right)_{\mathrm{H}_{2}},\left(\mathrm{k}_{\mathrm{L}} \mathrm{a}\right)_{\mathrm{CH}_{4}}\right.$ and $\left.\left(\mathrm{k}_{\mathrm{L}} \mathrm{a}\right)_{\mathrm{CO}_{2}}\right)$ and the hydrogen injection rate. Results of this analysis with the parameters that had an influence on the output variables can be seen in Figure 6, where the closer the column is to a PRCC value of 1 or -1 , the higher the impact of the parameter is on the output variable ( $\mathrm{pH}$, biogas, $\mathrm{CH}_{4}, \mathrm{CO}_{2}, \mathrm{H}_{2}$, TAN). A positive and a negative PRCC value mean a proportional and an inverse impact on the variable, respectively.

Firstly, none of the hydrogen inhibition constants had a significant impact on $\mathrm{pH}$, gas rates and ammonia concentration. The only constant that showed slight impact 
(smaller than 0.17 ) on methane and carbon dioxide volumetric rates was the inhibition constant for the butyrate acetogenic step $\left(\mathrm{K}_{\mathrm{i}, \mathrm{H}_{2}, \mathrm{X}_{6}}\right)$. This is due to the extremely low values of such constants in the model (in the order of $10^{-6} \mathrm{~g} \mathrm{~L}^{-1}$ ), implying low hydrogen inhibition in the acetogenic steps.

The model is highly sensitive to hydrogen injection rate, as expected. It has a strong positive impact on $\mathrm{pH}$, biogas, methane and evidently hydrogen in the gas phase, and a negative impact on $\mathrm{CO}_{2}$ and ammonia concentration. As more molecular hydrogen is injected in the reactor, partial pressure of $\mathrm{H}_{2}$ increases. Along with that also the concentration of $\mathrm{H}_{2}$ in the thermodynamic equilibrium is increased and subsequently the concentration of $\mathrm{H}_{2}$ in the liquid phase rises. Therefore, the negative impact on $\mathrm{CO}_{2}$ and ammonia concentration is due to the increased consumption of this gas by hydrogenotrophic methanogens and the utilization of nitrogen for their growth, when more hydrogen is soluble in the liquid phase.

Furthermore, the model proved to be quite sensitive to the hydrogen mass transfer coefficient $\left(\mathrm{k}_{\mathrm{L}} \mathrm{a}\right)_{\mathrm{H}_{2}}$, since it regulates the quantity of hydrogen being dissolved in the liquid and thereby being consumed by the microorganisms. $\left(\mathrm{k}_{\mathrm{L}} \mathrm{a}\right)_{\mathrm{H}_{2}}$ has a positive impact on $\mathrm{pH}$ and methane production, since these two variables increase as more hydrogen is dissolved in the liquid, and a negative impact on $\mathrm{CO}_{2}$ and ammonia concentration. The analysis could not correlate the biogas variable directly to the $\left(k_{L} a\right)_{H_{2}}$, since biogas is a variable that is dependent on all gaseous compounds.

The model was sensitive to the mass transfer coefficients of methane and carbon dioxide $\left(\left(\mathrm{k}_{\mathrm{L}} \mathrm{a}\right)_{\mathrm{CH}_{4}}\right.$ and $\left.\left.\left(\mathrm{k}_{\mathrm{L}} \mathrm{a}\right)_{\mathrm{CO}_{2}}\right)\right)$ as well, but not in the same order of magnitude as for 
$\left(\mathrm{k}_{\mathrm{L}} \mathrm{a}\right)_{\mathrm{H}_{2}}$. This result was obtained because values below $0.04 \mathrm{~h}^{-1}$ (which limit the mass transfer) were also tested by the model. It is possible to observe that $\mathrm{pH}$ and biogas rate increase as more gas is released from the liquid. $\mathrm{pH}$ increases with $\left(\mathrm{k}_{\mathrm{L}} \mathrm{a}\right)_{\mathrm{CO}_{2}}$. When the $\mathrm{pH}$ increases, the physical-chemical equilibrium between carbonate species is resulting in decrease in $\mathrm{HCO}_{3}{ }^{-}$concentration. $\mathrm{pH}$ is also affected positively by $\left(\mathrm{k}_{\mathrm{L}} \mathrm{a}\right)_{\mathrm{CH}_{4}}$ (although not as strongly as by $\left(\mathrm{k}_{\mathrm{L}} \mathrm{a}\right)_{\mathrm{CO}_{2}}$ ) because, as more methane is released into the biogas, the equilibrium between gas and liquid phase is altered and more methane has to be produced by the microorganisms. The majority of methane is produced by aceticlastic methanogens that consume acetic acid (and ammonia), therefore causing a $\mathrm{pH}$ increase and a decrease in ammonia concentration.

Presumably, the model is more sensitive to the $\left(\mathrm{k}_{\mathrm{L}} \mathrm{a}\right)_{\mathrm{H}_{2}}$ compared to $\left(\mathrm{k}_{\mathrm{L}} \mathrm{a}\right)_{\mathrm{CH}_{4}}$ and $\left(\mathrm{k}_{\mathrm{L}} \mathrm{a}\right)_{\mathrm{CO}_{2}}$, due to the low solubility of the hydrogen gas in the liquid phase (the Henry constant for hydrogen being $7.2 \mathrm{M} \cdot \mathrm{atm}^{-1}$ at $55^{\circ} \mathrm{C}$ ), which makes it less available in the liquid phase. Consequently, the difference between the concentrations is less important than the mass transfer coefficient.

Finally, all four kinetic constants for hydrogenotrophic methanogens have no significant influence on the chosen output variables. The saturation constant for hydrogen utilization, $\mathrm{K}_{\mathrm{S}, \mathrm{X}_{9}}$, did not present significant influence on any of the output variables due to its extremely low value $\left(3.13 \cdot 10^{-7} \mathrm{~g} \cdot \mathrm{L}^{-1}\right)$, therefore it is not depicted in Figure 6.

At the same time, while the maximum growth rate of the hydrogenotrophic methanogens $\left(\mu_{\max , X_{9}}\right)$ affects ammonia concentration mildly, it has a strong influence 
(PRCC of -0.82) on the hydrogen concentration in the liquid phase. However, since hydrogen is the main substrate for these microorganisms, this correlation is not shown in Figure 6. It can also be seen that the saturation constant for ammonia utilization only affects ammonia concentration slightly.

The death constant for the hydrogenotrophic methanogens had a minor effect on $\mathrm{pH}, \mathrm{CO}_{2}$ in the gas phase and ammonia concentration This is because the death constant is only $5 \%$ of $\mu_{\max , x_{9}}$, which is extremely high compared to other microbial groups $\left(0.33 \mathrm{~h}^{-1}\right)$, so there is a reduced effect of this variable.

\section{Conclusions}

The biogas upgrading process by in-situ hydrogen injection was described mathematically and was included in a previous mathematical model. The updated model was successfully validated by two Case Studies, with notably accurate predictions for biogas compositions and rates, $\mathrm{pH}$ and total ammonia concentrations. The prediction of VFA concentrations, however, remained to be a challenging task. Upon performing a model sensitivity analysis, the model output was found to be highly sensitive to the hydrogen injection rate and $\mathrm{k}_{\mathrm{L}}$ a parameters. Overall, the updated model proved to be an effective tool for predicting process performance in anaerobic co-digestion scenarios with biogas upgrading.

\section{Acknowledgements}

This study was supported by the São Paulo Research Foundation (FAPESP \#2014/07692-8, \#2015/06246-7, \#2016/12773-2), the National Council for Scientific and Technological Development (CNPq), the Coordination for the Improvement of 
Higher Education Personnel (CAPES), Energinet.dk, through the project ForskEL12197 titled “Improving synergy and robustness of manure co-digestion process" and the Danish Council for Strategic Research under the project "SYMBIO - Integration of biomass and wind power for biogas enhancement and upgrading via hydrogen assisted anaerobic digestion", contract 12-132654.

\section{Conflict of interest}

The authors claim no conflict of interest concerning any part of the work presented here.

\section{References}

1. Angelidaki, I., Chen, X., Cui, J., Kaparaju, P., Ellegaard, L., 2006. Thermophilic anaerobic digestion of source-sorted organic fraction of household municipal solid waste: Start-up procedure for continuously stirred tank reactor. Water Res. 40, 26212628. doi:10.1016/j.watres.2006.05.015

2. Angelidaki, I., Ellegaard, L., Ahring, B.K., 1999. A comprehensive model of anaerobic bioconversion of complex substrates to biogas. Biotechnol. Bioeng. 63, 363372. doi:10.1002/(SICI)1097-0290(19990505)63:3<363::AID-BIT13>3.0.CO;2-Z 3. Angelidaki, I., Ellegaard, L., Ahring, B.K., 1993. A mathematical model for dynamic simulation of anaerobic digestion of complex substrates: Focusing on ammonia inhibition. Biotechnol. Bioeng. 42, 159-166. doi:10.1002/bit.260420203 4. $\quad$ Bassani, I., Kougias, P.G., Angelidaki, I., 2016. In-situ biogas upgrading in thermophilic granular UASB reactor: key factors affecting the hydrogen mass transfer rate. Bioresour. Technol. 221, 485-491. doi:10.1016/j.biortech.2016.09.083

5. Bassani, I., Kougias, P.G., Treu, L., Angelidaki, I., 2015. Biogas Upgrading via Hydrogenotrophic Methanogenesis in Two-Stage Continuous Stirred Tank Reactors at Mesophilic and Thermophilic Conditions. Environ. Sci. Technol. 49, 12585-12593. doi:10.1021/acs.est.5b03451

6. Batstone, D.J., Keller, J., Angelidaki, I., Kalyuzhnyi, S. V, Pavlostathis, S.G., Rozzi, A., Sanders, W.T., Siegrist, H., Vavilin, V.A., 2002. The IWA Anaerobic Digestion Model No 1 (ADM1). Water Sci. Technol. 45, 65-73.

7. Costello, D.J., Greenfield, P.F., Lee, P.L., 1991. Dynamic modelling of a single stage high rate anaerobic reactor-I. Model derivation and II. Model verification. Water Res. doi:http://dx.doi.org/10.1016/0043-1354(91)90167-O

8. $\quad$ Feng, Y., Behrendt, J., Wendland, C., Otterpohl, R., 2006. Parameters Analysis and Discussion of the IWA Anaerobic Digestion Model No . 1 ( ADM1 ) for the Anaerobic Digestion of Blackwater plus Kitchen Refuse. Water Sci. Technol. 54, 139- 
147. doi:10.2166/wst.2006.535

9. Fitamo, T., Boldrin, A., Boe, K., Angelidaki, I., Scheutz, C., 2016a. Codigestion of food and garden waste with mixed sludge from wastewater treatment in continuously stirred tank reactors. Bioresour. Technol. 206, 245-254.

doi:https://doi.org/10.1016/j.biortech.2016.01.085

10. Fitamo, T., Boldrin, A., Dorini, G., Boe, K., Angelidaki, I., Scheutz, C., 2016b. Optimising the anaerobic co-digestion of urban organic waste using dynamic bioconversion mathematical modelling. Water Res. 106, 283-294.

doi:10.1016/j.watres.2016.09.043

11. Garcia-Robledo, E., Ottosen, L.D.M., Voigt, N. V, Kofoed, M.W., Revsbech, N.P., 2016. Micro-scale H2-CO2 Dynamics in a Hydrogenotrophic Methanogenic Membrane Reactor. Front. Microbiol. 7. doi:10.3389/fmicb.2016.01276 12. Hill, D.T., 1982. A Comprehensive Dynamic Model for Animal Waste Methanogenesis. Trans. ASAE 25, 1374-1380. doi:10.13031/2013.33730)

13. Hoare, A., Regan, D.G., Wilson, D.P., 2008. Sampling and sensitivity analyses tools (SaSAT) for computational modelling. Theor. Biol. Med. Model. 5.

doi:10.1186/1742-4682-5-4

14. Hullu, J., Maassen, J.I.W., van Meel, P.A., Shazad, S., Vaessen, J.M.P., Bini, L., Reijenga, J.C., 2008. Comparing di $\square$ erent biogas upgrading techniques.

15. Kougias, P.G., Treu, L., Benavente, D.P., Boe, K., Campanaro, S., Angelidaki, I., 2017. Ex-situ biogas upgrading and enhancement in different reactor systems. Bioresour. Technol. 225, 429-437. doi:10.1016/j.biortech.2016.11.124

16. Kovalovszki, A., Alvarado-Morales, M., Fotidis, I.A., Angelidaki, I., 2017. A systematic methodology to extend the applicability of a bioconversion model for the simulation of various co-digestion scenarios. Bioresour. Technol. 235, 157-166. doi:10.1016/j.biortech.2017.03.101

17. Lima, D.M.F., Rodrigues, J.A.D., Boe, K., Alvarado-Morales, M., Ellegaard, L., Angelidaki, I., 2016. Anaerobic modeling for improving synergy and robustness of a manure co-digestion process. Brazilian J. Chem. Eng. 33, 871-883. doi:10.1590/01046632.20160334s20150314

18. Luo, G., Angelidaki, I., 2013. Co-digestion of manure and whey for in situ biogas upgrading by the addition of $\mathrm{H} 2$ : Process performance and microbial insights. Appl. Microbiol. Biotechnol. 97, 1373-1381. doi:10.1007/s00253-012-4547-5

19. Luo, G., Johansson, S., Boe, K., Xie, L., Zhou, Q., Angelidaki, I., 2012. Simultaneous hydrogen utilization and in situ biogas upgrading in an anaerobic reactor. Biotechnol. Bioeng. 109, 1088-1094. doi:10.1002/bit.24360

20. Mata-Alvarez, J., Dosta, J., Romero-Güiza, M.S., Fonoll, X., Peces, M., Astals, S., 2014. A critical review on anaerobic co-digestion achievements between 2010 and 2013. Renew. Sustain. Energy Rev. 36, 412-427. doi:10.1016/j.rser.2014.04.039

21. Muñoz, R., Meier, L., Diaz, I., Jeison, D., 2015. A review on the state-of-the-art of physical/chemical and biological technologies for biogas upgrading. Rev. Environ.

Sci. Biotechnol. 14, 727-759. doi:10.1007/s11157-015-9379-1

22. Osorio, F., Torres, J.C., 2009. Biogas purification from anaerobic digestion in a wastewater treatment plant for biofuel production. Renew. Energy 34, 2164-2171. doi:10.1016/j.renene.2009.02.023

23. Pauss, A., Andre, G., Perrier, M., Guiot, S.R., 1990. Liquid-to-Gas mass transfer in anaerobic processes: Inevitable transfer limitations of methane and hydrogen in the biomethanation process. Appl. Environ. Microbiol. 56, 1636-1644. 
24. Siegrist, H., Vogt, D., Garcia-Heras, J.L., Gujer, W., 2002. Mathematical model for meso- and thermophilic anaerobic sewage sludge digestion. Environ. Sci. Technol. 36, 1113-1123. doi:10.1021/es010139p

25. Sun, Q., Li, H., Yan, J., Liu, L., Yu, Z., Yu, X., 2015. Selection of appropriate biogas upgrading technology-a review of biogas cleaning, upgrading and utilisation.

Renew. Sustain. Energy Rev. 51, 521-532. doi:10.1016/j.rser.2015.06.029

26. Ursua, A., Gandia, L.M., Sanchis, P., 2012. Hydrogen Production From Water Electrolysis: Current Status and Future Trends. Proc. IEEE 100, 410-426.

doi:10.1109/JPROC.2011.2156750

27. Weinrich, S., Nelles, M., 2015. Critical comparison of different model structures for the applied simulation of the anaerobic digestion of agricultural energy crops.

Bioresour. Technol. 178, 306-312. doi:10.1016/j.biortech.2014.10.138 


\section{FIGURE CAPTIONS}

Fig. 1. Pathways of the BioModel including the in-situ hydrogen upgrading.

Fig. 2. Case Study 1: Comparison of experimental and simulated biogas and methane rate (a), $\mathrm{pH}$ and total ammonia concentrations (b) and total VFA concentrations (c), where the continuous lines indicate the BioModel simulation, dashed lines indicate Kovalovszki et al. (2017) simulation and markers indicate experimental data (carried out by Fitamo et al. 2016). Dashed vertical lines represent the boundaries between feeding periods.

Fig. 3. Case Study 2: Comparison of experimental and simulated biogas and methane rate (a), pH and total ammonia concentrations (b) and total VFA concentrations (c), where the continuous lines indicate the BioModel simulation and markers indicate experimental data (carried out by Luo et al. 2016-Control Reactor).

Fig. 4. Case Study 2: Comparison of experimental and simulated biogas, methane and hydrogen rate (a) and composition b), $\mathrm{pH}$ and total ammonia concentrations (c) and total VFA concentrations (d), where the continuous lines indicate the BioModel simulation and markers indicate experimental data (carried out by Luo et al. 2016 - Reactor with $\mathrm{H}_{2}$ injection). Dashed vertical lines represent the boundaries between different $\mathrm{k}_{\mathrm{L}}$ a values.

Fig. 5. Case Study 3: Comparison of experimental and simulated biogas, methane and hydrogen rate (a) and composition (b), $\mathrm{pH}$ and total ammonia concentrations (c) and total VFA concentrations (d), where the continuous lines indicate the BioModel simulation and markers indicate experimental data (unpublished data). Dashed vertical lines represent the boundaries between different period with no hydrogen injection and with hydrogen injection.

Fig. 6. PRCC values of the included parameters in the BioModel for Case Study 3. Each indicator output variable is represented by a column and its size indicates the effect of respective parameters on the variable, on a scale of -1 to 1 . A larger absolute value means stronger effect, while the negative or positive sign implies an inverse or direct correlation, respectively. 
Table 1 Process data and operating conditions for Case Study 1.

\begin{tabular}{|c|c|c|c|c|c|c|}
\hline Parameter & $\begin{array}{l}\text { Period } 1 \\
\quad(\mathrm{P} 1)\end{array}$ & $\begin{array}{l}\text { Period } 2 \\
(\mathrm{P} 2)\end{array}$ & $\begin{array}{l}\text { Period } 3 \\
\text { (P3) }\end{array}$ & $\begin{array}{l}\text { Period } 4 \\
\text { (P4) }\end{array}$ & $\begin{array}{l}\text { Period } 5 \\
\text { (P5) }\end{array}$ & Reference \\
\hline Reactor volume (L) & \multicolumn{5}{|c|}{7.0} & \multirow{13}{*}{$\begin{array}{l}\text { Fitamo et al. } \\
\qquad(2016)\end{array}$} \\
\hline Temperature $\left({ }^{\circ} \mathrm{C}\right)$ & \multicolumn{5}{|c|}{55} & \\
\hline HRT (d) & 30 & 30 & 20 & 15 & 10 & \\
\hline Operating time $(\mathrm{d})$ & 74 & 56 & 34 & 40 & 26 & \\
\hline Mixed sludge (\%VS in the influent) & 100 & 10.0 & 10.0 & 10.0 & 10.0 & \\
\hline Food waste (\%VS in the influent) & 0 & 67.5 & 67.5 & 67.5 & 67.5 & \\
\hline Grass clippings (\%VS in the influent) & 0 & 15.75 & 15.75 & 15.75 & 15.75 & \\
\hline Garden waste (\%VS in the influent) & 0 & 6.75 & 6.75 & 6.75 & 6.75 & \\
\hline Total solids $\left[\mathrm{g} \cdot \mathrm{L}^{-1}\right]$ : & 26 & 87 & 87 & 87 & 87 & \\
\hline Volatile solids $\left[\mathrm{g} \cdot \mathrm{L}^{-1}\right]$ : & 18 & 74 & 74 & 74 & 74 & \\
\hline Total ammonia nitrogen $\left[\mathrm{g} \cdot \mathrm{L}^{-1}\right]$ : & 0.145 & 0.278 & 0.278 & Q & 0.278 & \\
\hline$\left(\mathrm{k}_{\mathrm{L}} \mathrm{a}\right)_{\mathrm{H}_{2}}\left[\mathrm{~h}^{-1}\right]$ & - & - & - & & - & \\
\hline $\begin{array}{l}\text { Hydrogen injection rate } \\
{\left[\mathrm{L} \cdot \mathrm{L}^{-1} \cdot \mathrm{d}^{-1}\right] \text { : }}\end{array}$ & - & - & - & & - & \\
\hline
\end{tabular}


Table 2 Process data and operating conditions for Case Study 2.

\begin{tabular}{|c|c|c|c|c|c|}
\hline Parameter & $\begin{array}{l}\text { Period } 1 \\
\text { (P1) }\end{array}$ & $\begin{array}{l}\text { Period } 2 \\
\quad(\mathrm{P} 2)\end{array}$ & $\begin{array}{l}\text { Period } 3 \\
\text { (P3) }\end{array}$ & $\begin{array}{l}\text { Period } 4 \\
\text { (P4) }\end{array}$ & Reference \\
\hline Reactor volume (L) & 1.0 & - & - & -- & \\
\hline Temperature $\left({ }^{\circ} \mathrm{C}\right)$ & 55 & - & - & - & \\
\hline HRT (d) & 15 & - & - & - & \\
\hline Operating time (d) & 20 & - & - & - & \\
\hline $\mathrm{pH}$ & 6.9 & - & - & - & \\
\hline Total solids $\left[\mathrm{g} \cdot \mathrm{L}^{-1}\right]$ : & 28.5 & - & - & - & \\
\hline Volatile solids $\left[\mathrm{g} \cdot \mathrm{L}^{-1}\right]$ : & 25 & - & - & - & Cont \\
\hline $\mathrm{COD}\left[\mathrm{g} \cdot \mathrm{L}^{-1}\right]:$ & 40 & - & - & - & Reactor \\
\hline Total nitrogen $\left[\mathrm{g} \cdot \mathrm{L}^{-1}\right]$ : & 0.701 & - & - & - & \\
\hline $\begin{array}{l}\text { Total ammonia nitrogen } \\
{\left[\mathrm{g} \cdot \mathrm{L}^{-1}\right] \text { : }}\end{array}$ & 0.330 & - & - & & \\
\hline$\left(\mathrm{k}_{\mathrm{L}} \mathrm{a}\right)_{\mathrm{H}_{2}}\left[\mathrm{~h}^{-1}\right]$ & - & - & - & & \\
\hline 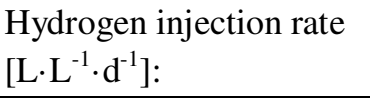 & - & - & & & \\
\hline Reactor volume (L) & & & & & \multirow{11}{*}{$\begin{array}{l}\text { Reactor with } \\
\mathrm{H}_{2} \text { injection }\end{array}$} \\
\hline Temperature $\left({ }^{\circ} \mathrm{C}\right)$ & & & & & \\
\hline HRT (d) & 15 & 15 & 15 & 15 & \\
\hline Operating time (d) & 20 & 45 & 45 & 45 & \\
\hline $\mathrm{pH}$ & 6.9 & 6.9 & 6.9 & 6.9 & \\
\hline Total solids $\left[\mathrm{g} \cdot \mathrm{L}^{-1}\right]$ : & 28.5 & 28.5 & 28.5 & 28.5 & \\
\hline Volatile solids $\left[\mathrm{g} \cdot \mathrm{L}^{-1}\right]$ : & 25 & 25 & 25 & 25 & \\
\hline $\operatorname{COD}\left[g \cdot L^{-1}\right]:$ & & 40 & 40 & 40 & \\
\hline Total nitrogen $\left[\mathrm{g} \cdot \mathrm{L}^{-1}\right]$ : & 0701 & 0.701 & 0.701 & 0.701 & \\
\hline $\begin{array}{l}\text { Total ammonia nitroge } \\
{\left[\mathrm{g} \cdot \mathrm{L}^{-1}\right]:}\end{array}$ & 0.330 & 0.330 & 0.330 & 0.330 & \\
\hline$\left(\mathrm{k}_{\mathrm{L}} \mathrm{a}\right)_{\mathrm{H}_{2}}\left[\mathrm{~h}^{-1}\right]$ & 6.6 & 6.6 & 11.2 & 16.2 & \\
\hline $\begin{array}{l}\text { Hydrogen injection rate } \\
{\left[\mathrm{L} \cdot \mathrm{L}^{-1} \cdot \mathrm{d}^{-1}\right]:}\end{array}$ & 1.5 & 1.7 & 1.7 & 1.7 & \\
\hline
\end{tabular}

Influent composition: diluted cheese whey (40\% of VS) and manure (60\% of VS) 
Table 3 Process data and operating conditions for Case Study 3.

\begin{tabular}{|c|c|c|c|}
\hline Parameter & $\begin{array}{l}\text { Period } 1 \\
\text { (P1) }\end{array}$ & $\begin{array}{l}\text { Period } 2 \\
(\mathrm{P} 2)\end{array}$ & Reference \\
\hline Reactor volume (L) & \multicolumn{2}{|c|}{1.8} & \multirow{12}{*}{$\begin{array}{c}\text { Unpublished } \\
\text { data }\end{array}$} \\
\hline Temperature $\left({ }^{\circ} \mathrm{C}\right)$ & \multicolumn{2}{|c|}{55} & \\
\hline $\operatorname{HRT}(d)$ & 15 & 15 & \\
\hline Operating time $(\mathrm{d})$ & 23 & 86 & \\
\hline $\mathrm{pH}$ & 4.5 & 4.5 & \\
\hline Total solids $\left[\mathrm{g} \cdot \mathrm{L}^{-1}\right]$ : & 64.9 & 64.9 & \\
\hline Volatile solids $\left[\mathrm{g} \cdot \mathrm{L}^{-1}\right]$ : & 55.6 & 55.6 & \\
\hline $\operatorname{COD}\left[g \cdot L^{-1}\right]:$ & 76 & 76 & \\
\hline Total nitrogen $\left[\mathrm{g} \cdot \mathrm{L}^{-1}\right]$ : & 8.7 & 8.7 & \\
\hline Total ammonia nitrogen $\left[\mathrm{g} \cdot \mathrm{L}^{-1}\right]$ : & 0.114 & 0.114 & \\
\hline$\left(\mathrm{k}_{\mathrm{L}} \mathrm{a}\right)_{\mathrm{H}_{2}}\left[\mathrm{~h}^{-1}\right]$ & - & 40 & \\
\hline $\begin{array}{l}\text { Hydrogen injection rate } \\
{\left[\mathrm{L} \cdot \mathrm{L}^{-1} \cdot \mathrm{d}^{-1}\right] \text { : }}\end{array}$ & - & 0.8 & \\
\hline
\end{tabular}

Influent composition: diluted cheese whey (80\% of VS) and manure (20\% of VS) 


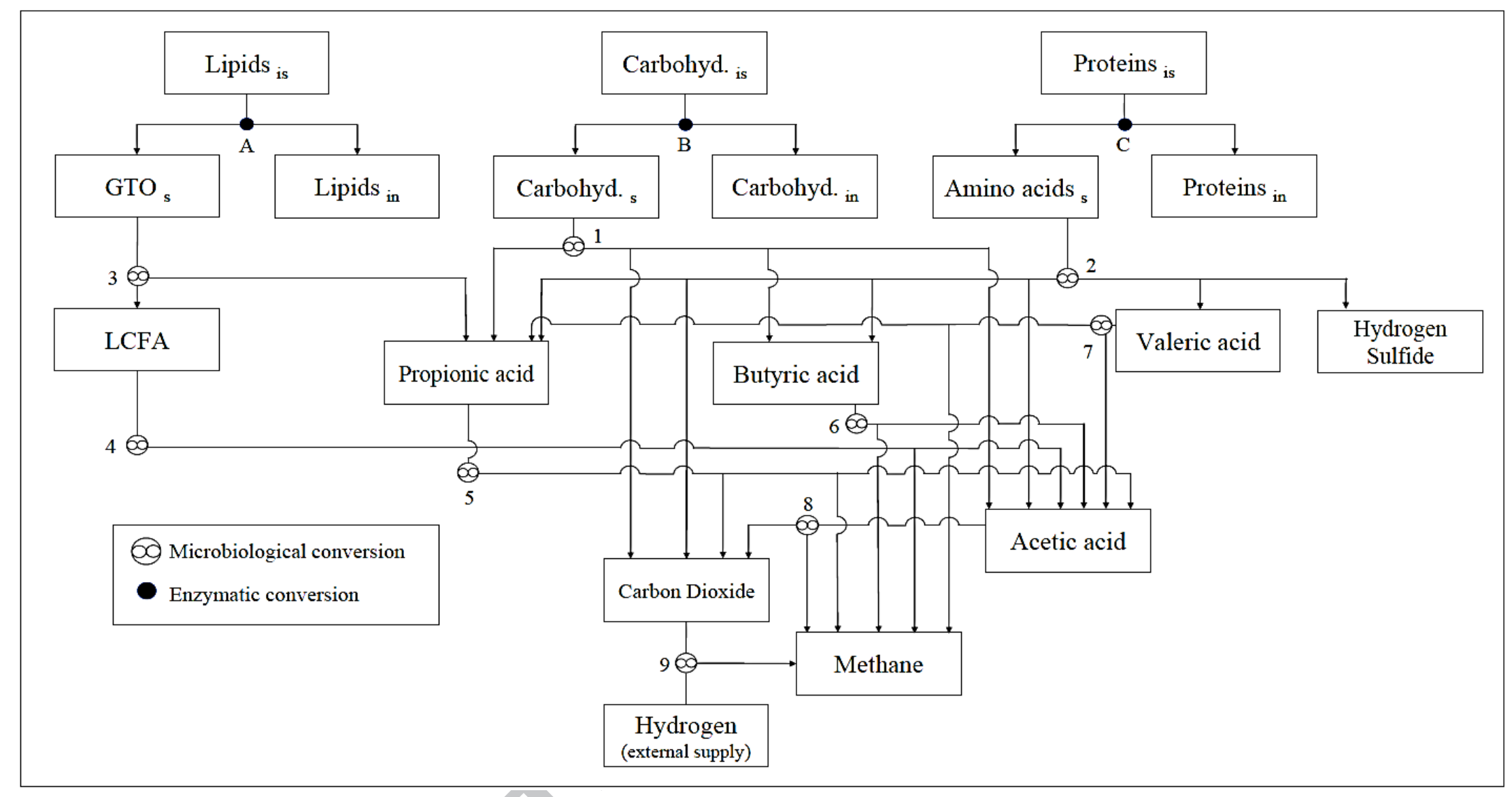

Fig. 1 

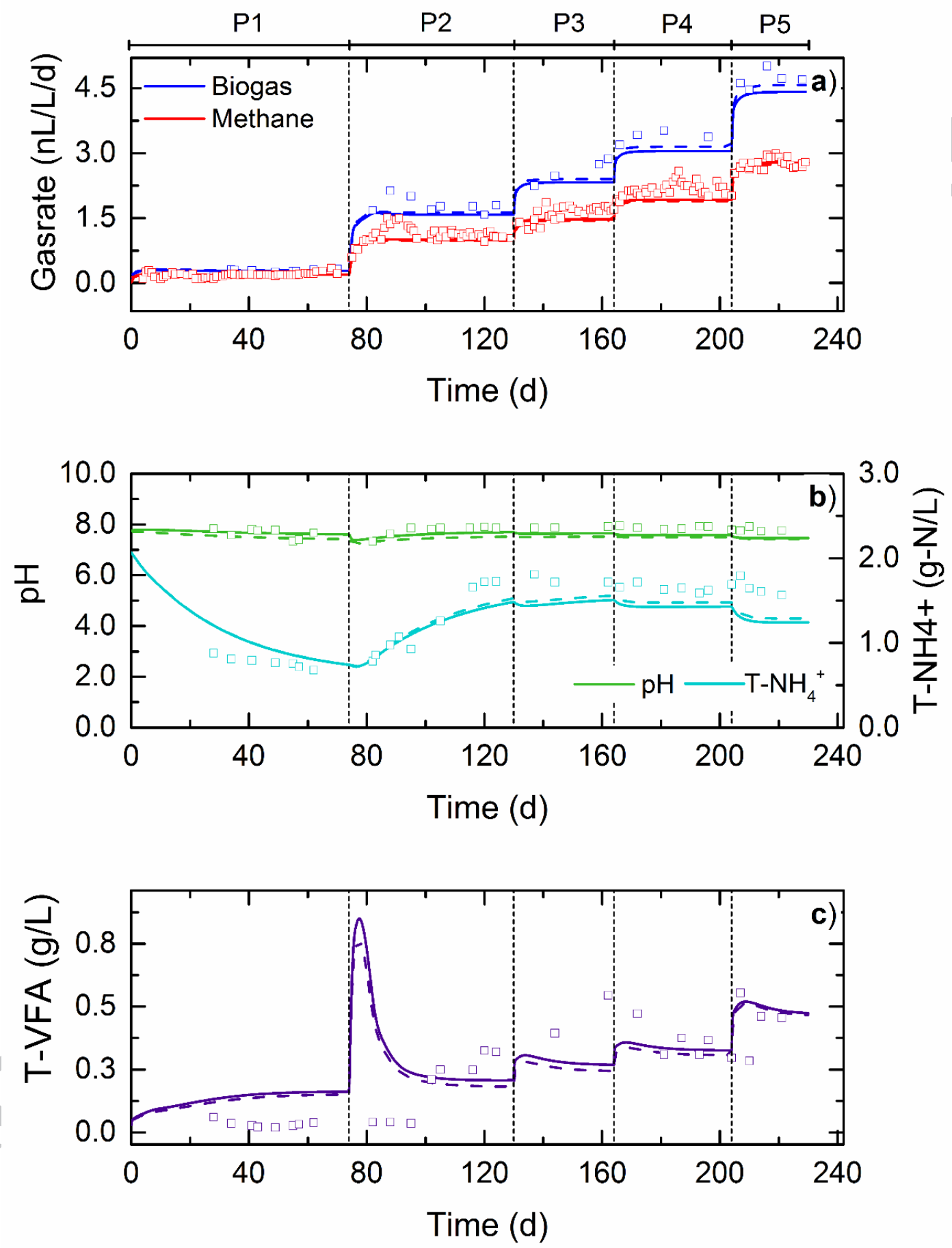

Fig. 2 

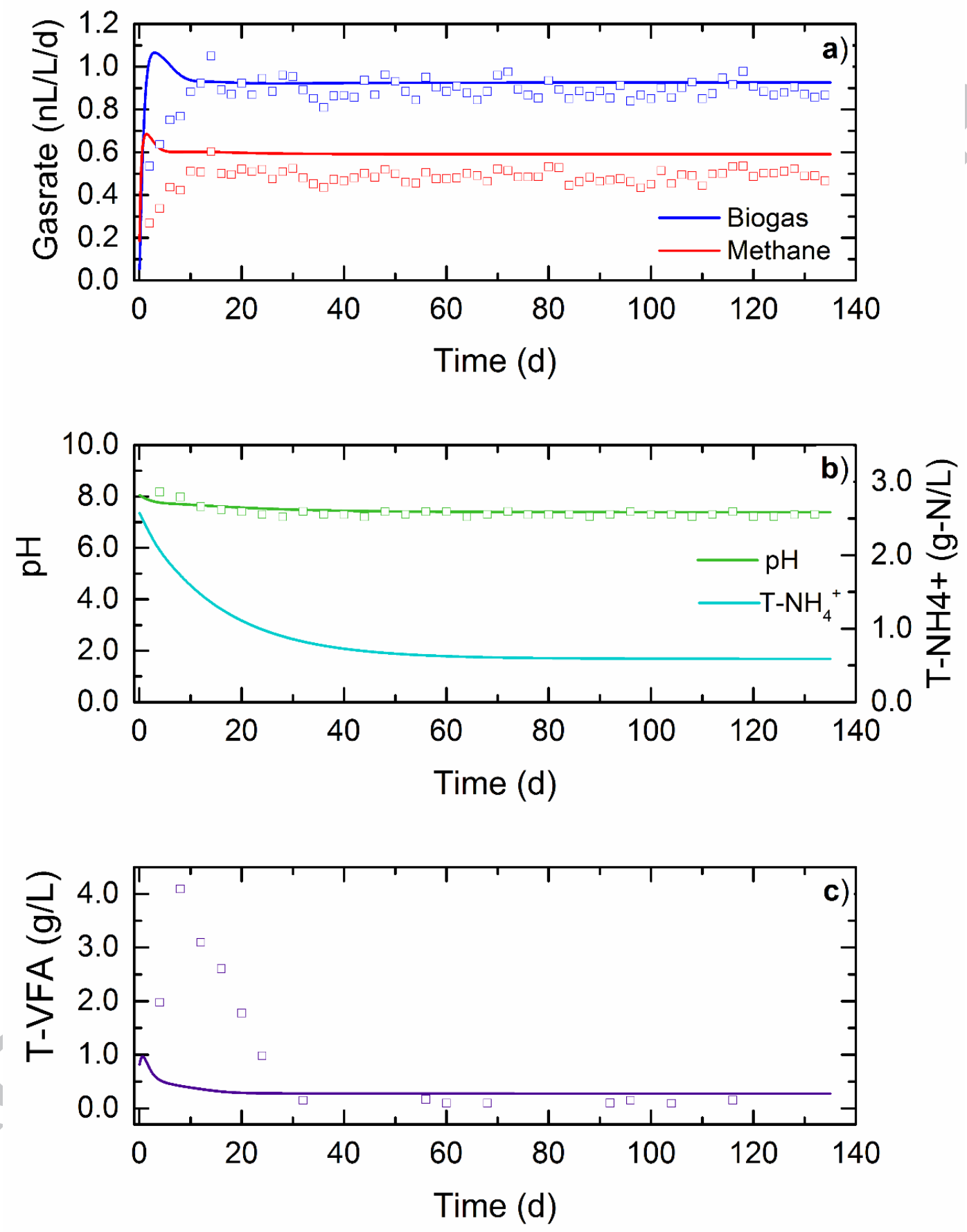

Fig. 3 

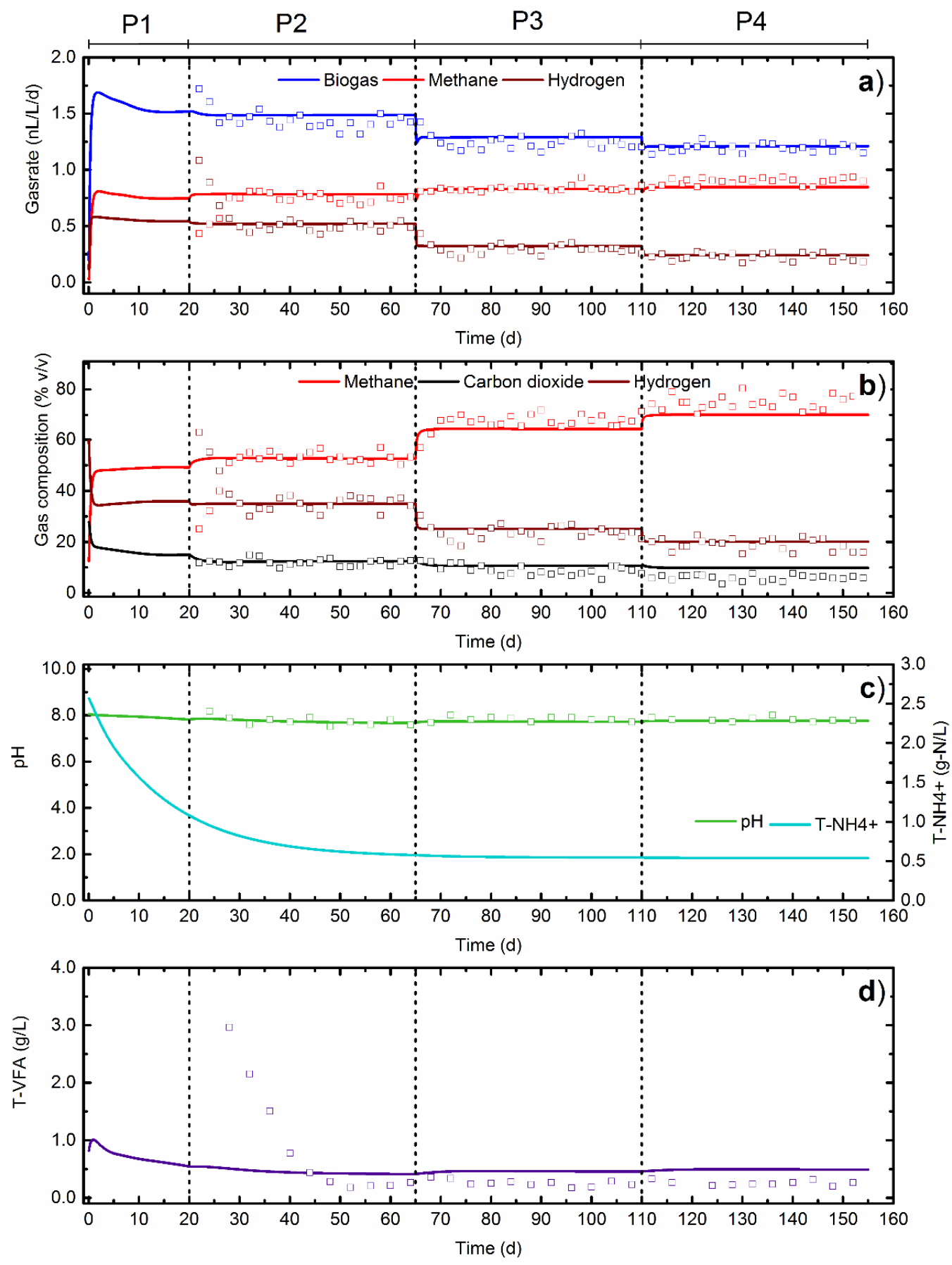

Fig. 4. 

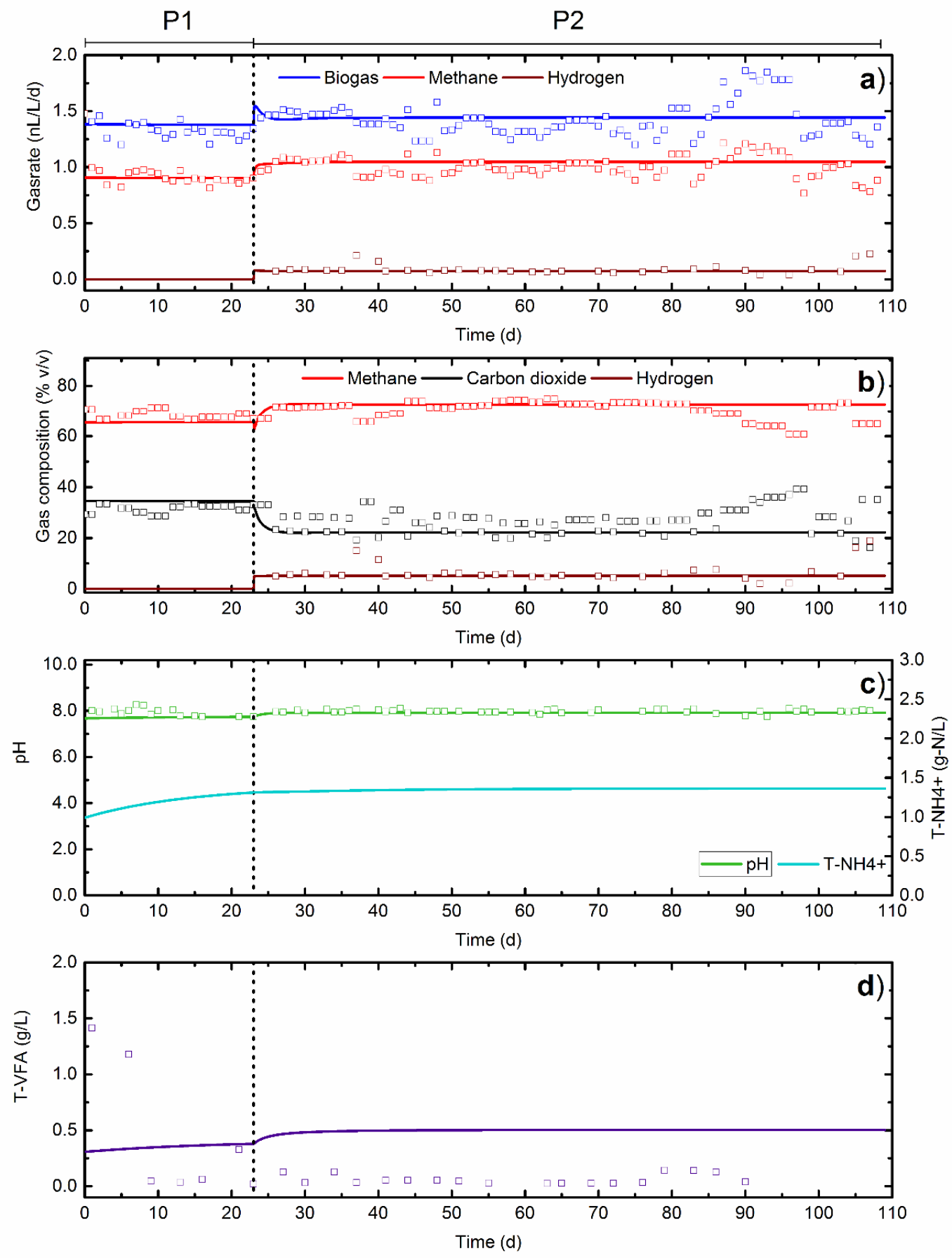

Fig. 5 


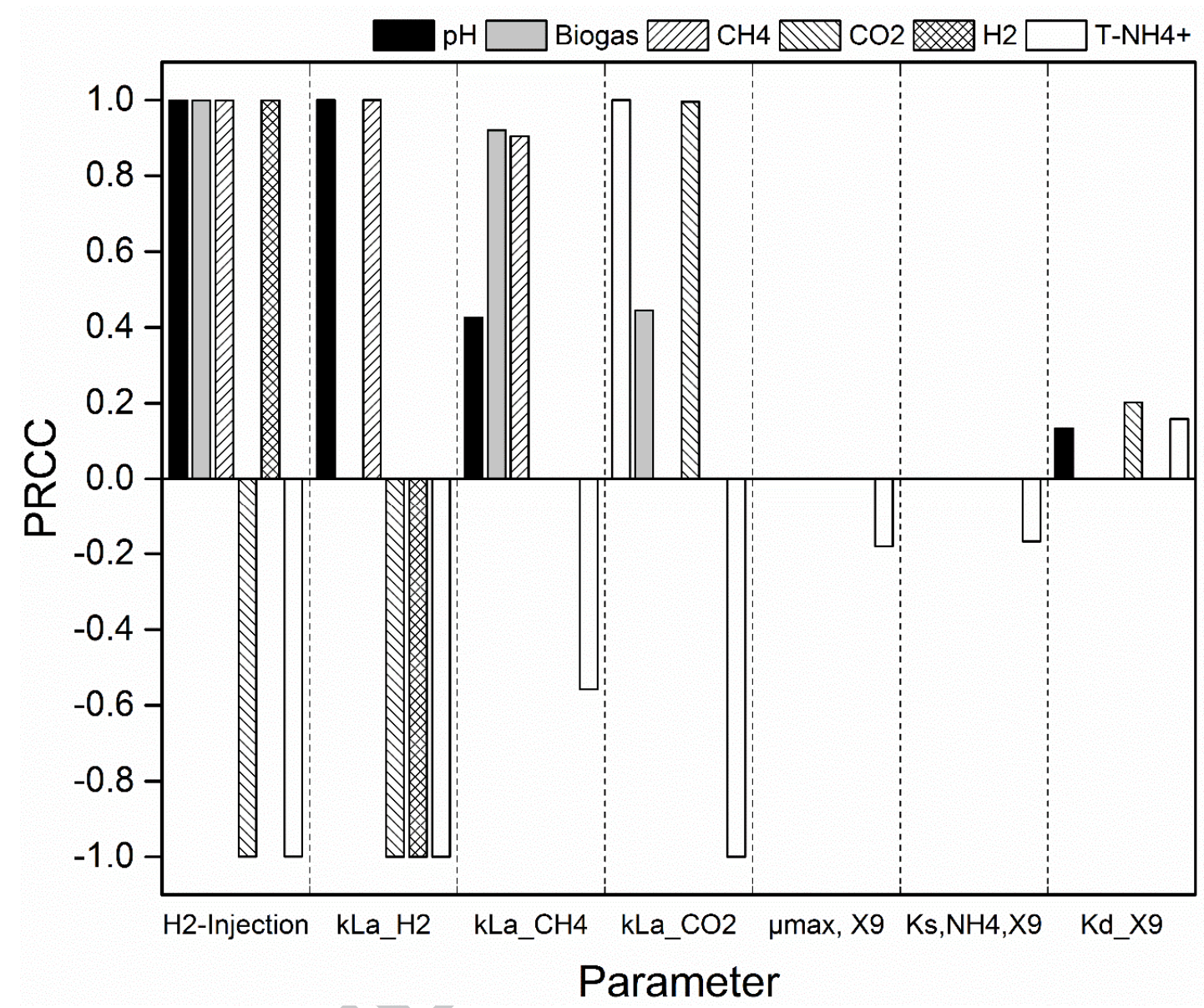

Fig. 6 


\section{HIGHLIGHTS}

- The biological biogas upgrading process by in-situ hydrogen injection was modeled;

- Hydrogenotrophic kinetics and hydrogen balance was added to a previous model;

- The model was effective in predicting biogas, methane and hydrogen rates;

- $\mathrm{pH}$ and ammonia simulation were also well predicted;

- The model is highly sensitive to hydrogen injection and mass transfer coefficients. 


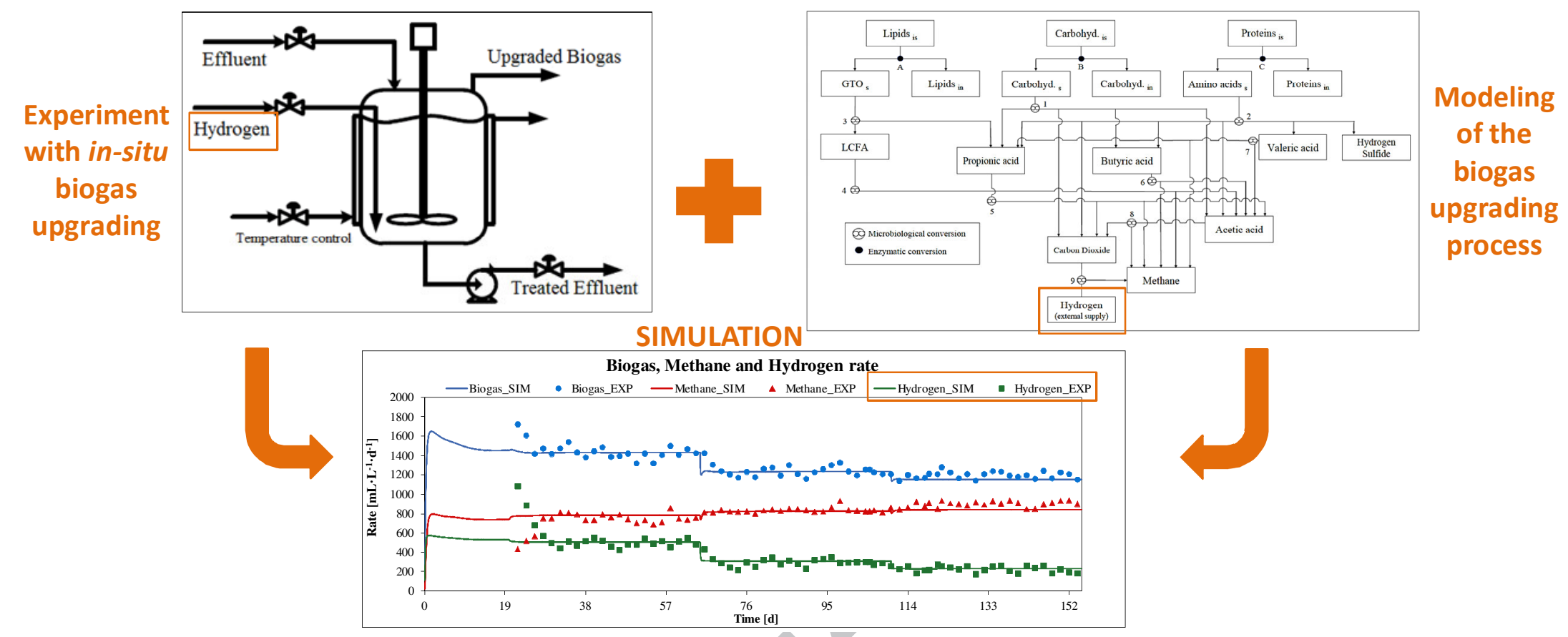

